\title{
Flower-Visiting Social Wasps and Plants Interaction: Network Pattern and Environmental Complexity
}

\author{
Mateus Aparecido Clemente, ${ }^{1}$ Denise Lange, ${ }^{2}$ Kleber Del-Claro, ${ }^{2}$ Fábio Prezoto, ${ }^{1}$ \\ Núbia Ribeiro Campos, ${ }^{3}$ and Bruno Corrêa Barbosa ${ }^{4}$ \\ ${ }^{1}$ Programa de Pós-Graduação em Ciências Biológicas, Universidade Federal de Juiz de Fora, 36036-900 Juiz de Fora, MG, Brazil \\ ${ }^{2}$ Laboratório de Ecologia Comportamental e de Interações (LECI), Instituto de Biologia, Universidade Federal de Uberlândia, \\ P.O. Box 593, 38400-902 Uberlândia, MG, Brazil \\ ${ }^{3}$ Instituto de Biologia, Universidade Federal de Ouro Preto, 35400-000 Ouro Preto, MG, Brazil \\ ${ }^{4}$ Curso de Ciências Biológicas, Centro de Ensino Superior de Juiz de Fora, 36033-240 Juiz de Fora, MG, Brazil
}

Correspondence should be addressed to Denise Lange, deniselange@yahoo.com.br

Received 29 August 2012; Accepted 9 October 2012

Academic Editor: Helena Maura Torezan-Silingardi

Copyright () 2012 Mateus Aparecido Clemente et al. This is an open access article distributed under the Creative Commons Attribution License, which permits unrestricted use, distribution, and reproduction in any medium, provided the original work is properly cited.

\begin{abstract}
Network analysis as a tool for ecological interactions studies has been widely used since last decade. However, there are few studies on the factors that shape network patterns in communities. In this sense, we compared the topological properties of the interaction network between flower-visiting social wasps and plants in two distinct phytophysiognomies in a Brazilian savanna (Riparian Forest and Rocky Grassland). Results showed that the landscapes differed in species richness and composition, and also the interaction networks between wasps and plants had different patterns. The network was more complex in the Riparian Forest, with a larger number of species and individuals and a greater amount of connections between them. The network specialization degree was more generalist in the Riparian Forest than in the Rocky Grassland. This result was corroborated by means of the nestedness index. In both networks was found asymmetry, with a large number of wasps per plant species. In general aspects, most wasps had low niche amplitude, visiting from one to three plant species. Our results suggest that differences in structural complexity of the environment directly influence the structure of the interaction network between flower-visiting social wasps and plants.
\end{abstract}

\section{Introduction}

Wasps are a significant portion of the flower-visiting guild that may overlap bees in nectar exploitation in several ecosystems $[1,2]$. Although wasps are more frequently regarded as floral resource thieves [3-6], recent papers show that wasps can also effectively contribute to pollination [7]. In a study with Schinus terebinthifolius Raddi (Anacardiaceae), Sühs et al. [8] showed that social wasps, especially Polistes versicolor (Olivier, 1791), Polybia sericea (Olivier, 1791), Polistes simillimus (Zikán, 1951), and Polybia ignobilis (Haliday, 1836), were more representative in richness and abundance than bee species, being considered efficient pollinators. Other studies, such as Barros [9] and Hermes and Köhler [10] also demonstrated the efficiency of the wasps as pollinators. Thus, social wasp-plant interaction networks can be considered nonobligatory mutualistic associations.
Interaction networks between plants and their floral visitors are currently among the most widely studied interactions (see review by [11]). The structure of these networks, almost always characterized by mutualistic interactions (pollinators and plants), exhibits a common pattern of nestedness and asymmetry $[6,12-14]$ with varied specialization degree $[15,16]$. According to Blüthgen et al. [15], pollinator webs were highly asymmetric, involving a much higher number of pollinators (usually insects) than plant species. Consequently, pollinators are significantly less specialized on plants than plants on pollinators. On the other hand, the nested pattern common in mutualistic networks means that species with few links interact with a subset of interactive partners with high connectivity [12]. In those webs, the species with many links (hubs species) are the most generalists and give support to network pattern according to Bastolla et al. [17]. Thus, the properties of interaction networks of plant 
pollinator tend to generalization, even though they are on average more specialized than networks of other mutualisms, such as seed dispersal and the use of extrafloral nectaries [14].

Recent network analyses revealed that plant-pollinator interactions display an intermediate level of complementary specialization [16]. According to Blüthgen and Klein [18], specialization and complementarity are related: complementarity requires a certain degree of specialization of each species, while high generalization is associated with high niche overlap and thus redundancy. Therefore, plantpollinator interactions exhibit an intermediate structure between generalization and specialization (represented by nestedness, asymmetry, and intermediate level of complementary specialization). These proprieties make these interaction networks robust and more stable to species extinction $[17,19-21]$.

Studies on the structure of interaction networks between plants and flower-visiting social wasps are scarce $[6,22]$, as well as knowledge about the diversity of wasps in various environments [1, 10,23]. In Brazil, studies on the sources of floral resources used by social wasps were carried out in Cerrado (the Brazilian Savanna) [24-26], in an Araucaria Forest [10], in urban areas [27], and in Brazilian Caatinga (a semiarid scrub forest) [28]. Furthermore, there are only two studies dealing with the interaction network between plants and flower-visiting social wasps in Brazil $[6,22]$, and these studies show only the general pattern of interactions or compare these patterns with networks involving other groups of floral visitors.

Most studies concerning ecological interaction networks relate the network structural pattern with the type of relationship established between the groups of organisms, without taking into account the characteristics of the environment in which the interaction takes place (e.g., $[16,29])$. Thus, it becomes difficult to understand the actual biological importance of the interactions. However, interactions are known to be strongly variable in time and space [30-32]. It is known that more structurally complex environments (represented for greater availability of food resources and nesting sites) have greater richness and diversity of species $[33,34]$, including social wasps $[35,36]$. According to Santos [35], vegetation structure influences social wasp communities because it provides support for nesting, food resources, resources for building nests, and foraging area. Thus, hypothetically, environments with different complexities may have interaction networks with different topological properties and, consequently, different specialization degree. Therefore, in this study we propose to know the structure of the interaction network between flower-visiting social wasps and plants in two distinct phytophysiognomies in a Brazilian Savanna area, and to compare them mainly in terms of network structure and its specialization degree.

\section{Materials and Methods}

2.1. Study Area and Data Sample. We carried out the field collections in the period from November 2007 to October 2008 in two phytophysiognomies (Riparian Forest and Rocky
Grassland) of the neotropical savanna reserve of Parque Estadual do Ibitipoca (PEIB) (Ibitipoca State Park), which is localized in Serra de Ibitipoca (Ibitipoca Mountains), MG, Brazil. The area covers 1,488 hectares at coordinates $21^{\circ} 40^{\prime} 44^{\prime} \mathrm{S}$ and $43^{\circ} 52^{\prime} 55^{\prime} \mathrm{W}$. According to the Köppen classification, the climate of this region is Cwb (humid mesothermal regime with dry winters and rainy summers). The Riparian Forest exhibits a phytophysiognomic profile of transition from high-altitude savannas to ombrophilous forests, with a physiognomy sequence from shrubby arboreal to predominantly arboreal [37]. This area exhibits a great heterogeneity of plant species mainly due to variations in soil humidity [38]. Furthermore, Fontes [39] highlights the importance of persistence of cloudiness (i.e., high humidity) in this vegetation type. On the other hand, the Rocky Grassland physiognomy exhibits a xeromorphic aspect, with a wide diversity of herbs and shrubs distributed over quartzite outcrops [37]. This area is dominated by plants tolerant to water stress due to the high incidence of light and wind [40].

In each of these two physiognomies, we used one transect of the $800 \times 4 \mathrm{~m}$ for monthly examinations throughout the twelve months of study. The transects were $1200 \mathrm{~m}$ distant from each other for its independence. We carried out the monthly observations in two days between 7:00 and 17:00 h. During this period, we observed for $10 \mathrm{~min}$ all the plants that had flowers, and we collected one individual of each one of wasp specie that visited the flowers. This capture was made with an entomological sweep net, according to methods of Aguiar [41]. We identified and stored the plants in the CESJ Herbarium at the Universidade Federal de Juiz de Fora, Juiz de Fora, MG, Brazil (UFJF), with the following access numbers: 51321 to 51347,52165 , and 52166. We identified the wasp species according to Richards [42], and Carpenter and Marques [43], and we stored them at the UFJF entomological scientific collection.

2.2. Data Analysis. To get to know the network connectivity between plants and wasps in the areas of Riparian Forest and Rocky Grassland, we constructed two adjacency matrices (wasp in plant) per area: "quantitative matrix" considering frequency of interactions of each wasp species on each plant species and "qualitative matrix" with data of presence/ absence of the wasp species in plant species. The metrics that we used to check the properties of interaction networks were connectance, asymmetry, and nestedness index (NODF) using qualitative matrixes, and degree of complementary specialization $\left(H_{2}^{\prime}\right)$ using quantitative matrixes.

We calculated the connectance $(C)$ according to Jordano [44], where $C=I /(F * P)$, " $I$ " is the total number of interactions observed, " $F$ " is the number of wasp species, and " $P$ " is the number of plant species. Percent values of $C$ were obtained by multiplying it by 100 . We calculated the average degree for plants using the arithmetic means of degrees (= number of interactions in which each species was involved) of all plant species (sensu [45]); the same was carried out for wasps. We also calculated the balance between numbers of plant " $I$ " and wasps " $J$ " species in each network using 
the following equation: $W=(I-J) /(I+J)$, where " $W$ " is the web asymmetry. Values equal zero for balanced webs, positive numbers indicate more plant species, and negative more wasp species, rescaled to $(-1,1)$, see $[15,46]$. To estimate the nestedness value of networks, we used the NODF index: nestedness metric based on overlap and decreasing fill, see [47], calculated by the software Aninhado 3.0 [48]. We check the significance of $N O D F$ with a Monte Carlo procedure with 1,000 randomizations, using null model II, in which the interaction probability between a wasp and a plant is proportional to their total number of interactions. NODF index is strongly recommended due to its theoretical and statistical consistency [47].

In order to verify the degrees of networks specialization, we calculated the degree of complementary specialization $\left(H_{2}^{\prime}\right)$ for each network using the quantitative matrixes. This degree is derived from Shannon index, and it is robust to changes in sampling intensity and the number of interacting species in the network. It is based on the deviation from the expected probability distribution of the interactions (see $[15,49])$, and its results vary from 0 (extreme generalization) to 1.0 (extreme specialization).

Besides the metrics for network characterization, we calculated the specialization degree $\left(d^{\prime}\right)$ of the wasp species for each network. The $d^{\prime}$ index is a standardized measure of the Kullback-Leibler distance, which measures the specialization of a species based on the frequency of the total number of interactions in the network [49]. This index ranges from 0 to 1.0 indicating extreme generalization and specialization of the species, respectively [49]. We used the R software version 2.13.2 (freeware) to calculate the $H_{2}^{\prime}$ and $d^{\prime}$ indices and to construct the bipartite graph.

We also verify the importance of the plant species on the interaction with the wasps in both areas (Riparian Forest and Rocky Grassland). For this we used the importance index developed by Murray [50]. In the equation $I j=\Sigma[(\mathrm{Cij} / \mathrm{Ti}) / S]$, " $T i$ " is the total number of plant species visited by each wasp species, "S" the total number of visiting species, and " $\mathrm{Cij}$ " corresponded to the binary data $(0 / 1)$ (see also [6]). The values of this index range from 0 to 1.0 , where 1.0 is the maximum importance value of each plant species for each wasp species.

In addition, we verify the monthly diversity (Shannon index) of social wasps visiting flowers in each area studied using the PAST software (freeware). We compared the monthly values of diversity between areas using the MannWhitney test ( $U$-test) by the software BioEstat 4.0 (freeware). We also calculated the niche amplitude of social wasps by means of the Shannon index: $H^{\prime}=-\sum p_{k} \cdot \ln p_{k}$, where " $p_{k}$ " is the proportion of the individuals collected in a plant species " $k$," and "In" is the Neperian logarithm of the value " $p_{k}$."

\section{Results}

The interaction networks between wasps and plants in the two landscapes showed different patterns (Table 1). The network was more complex in the Riparian Forest, with a larger
TABLE 1: Metrics of networks for the wasp-plant interactions studied at Ibitipoca State Park, MG, Brazil, during the period from November 2007 to October 2008.

\begin{tabular}{lcc}
\hline Network metrics & Riparian forest & Rocky grassland \\
\hline Number of plant species & 18 & 11 \\
Number of wasp species & 15 & 8 \\
Number of associations & 44 & 14 \\
Degree of plant species & $2.44 \pm 0.57$ & $1.27 \pm 0.14$ \\
(average degree \pm SE) & & \\
Degree of wasp species & $2.93 \pm 0.62$ & $1.75 \pm 0.52$ \\
(average degree \pm SE) & $16.29 \%$ & $15.90 \%$ \\
Network connectance & 0.347 & 0.521 \\
$H_{2}^{\prime}$ index & 0.09 & 0.15 \\
Web asymmetry & $17.71, P<0.01$ & $11.61, P=0.51$ \\
Nestedness value (NODF)
\end{tabular}

number of species and individuals and a greater amount of connections between them (see Table 1, Figure 1, and Table 2). The network specialization degree $\left(H_{2}^{\prime}\right)$ was more generalist in the Riparian Forest than in the Rocky Grassland. This result was corroborated by means of the nestedness index $(N O D F)$, by which only the Riparian Forest presented a significant nestedness value (Table 1 ). The interactions in the Rocky Grassland tended towards specialization, with relatively high values of $H_{2}^{\prime}$ and nonsignificant nestedness. In both networks was found asymmetry, with a large number of wasps per plant species. The Riparian Forest had more wasp species diversity than Rocky Grassland $(U=105.5$; $P<$ 0.05). The composition of the plant community visited by wasps was different in the two phytophysiognomies. Moreover, the most important plant species in the Riparian Forest was also present in the Rocky Grassland, and also exhibiting high importance (Figure 2). Despite these differences, in both areas, the most important source of floral resources for social wasps, presenting the highest richness of visitors, was the species belonging to the Asteraceae family (with nine species). Baccharis sp.1 was the species that presented the greatest importance index for the wasp species in both phytophysiognomies (Figure 2). On the other hand, the families with only one visiting individual were Orchidaceae, (Prosthechea vespa (Sw.) W. E. Higgins), Lythraceae (Cuphea sp1), Fabaceae (Periandra sp1), Theaceae (Gordonia fruticosa (Schrad.) H. Keng), and Poaceae (Trachypogon spicatus (L. F.) Kuntze), with low importance for wasp in the network interactions here studied.

Although plant community visited by wasps was different between the two studied physiognomies, the most important plant species (specialists) in the Riparian Forest were also present in the Rocky Grassland. With the exception of two wasp species found only in the Riparian Forest, the landscapes presented the same wasp species. Of all wasp species observed in the Riparian Forest, Mischocyttarus confusus Zikán, 1935, was the most generalist, interacting with eight out of the 18 plant species (Figure 3 and Table 2). In Rocky Grassland, the species Mischocyttarus drewseni Saussure, 


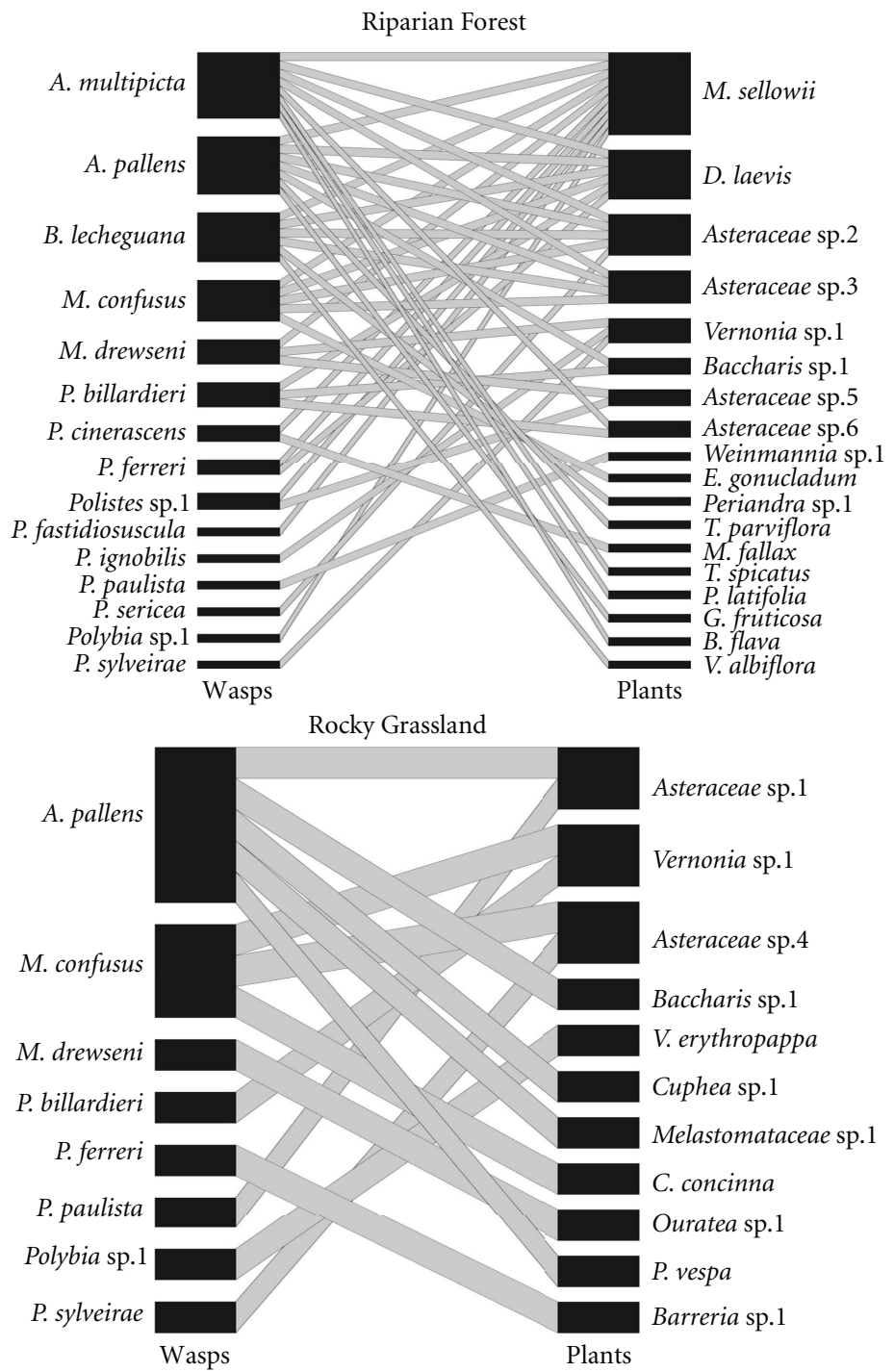

Figure 1: Wasp-plant interaction networks at Ibitipoca State Park, Minas Gerais, Brazil, during the period from November 2007 to October 2008. Riparian Forest: 18 plant species and 15 wasp species, Rocky Grassland: 11 plant species and eight wasp species (see Table 3 for classification and authors of species).

1857, was the species that presented higher level of generalization, interacting with five plant species. Furthermore, $M$. confusus and other five species (M. drewseni, Polybia paulista (von Ihering, 1896), Polybia sp1, Polistes billardieri Fabricius, 1804, and Protonectarina sylveirae (Saussure, 1854)) had an interaction degree higher than the average found to the group in Riparian Forest, all with degree of 2.93 (see Table 1). These species, with the exception of $P$. billardieri, were found in higher abundance in Riparian Forest. Looking for the wasp species interacting with only one plant, in both vegetation physiognomies we found six species in this condition. This represents $40 \%$ of Riparian Forest and $70 \%$ of Rocky Grassland species (Table 2).

In general aspects, most of wasps had low niche amplitude, visiting from one to three plant species (Table 2). In Riparian Forest, $M$. confusus and $M$. drewseni were the species with higher niche amplitude, visiting eight and seven plant species. In Rocky Grassland, the variation in niche amplitude was lower, from zero to 1.561 , and $M$. drewseni was the wasp with higher niche amplitude, visiting 11 plant species (Table 2). Some wasp species present the value zero in amplitude reflecting a very small number of observed interactions with distinct plant species.

\section{Discussion}

The structural aspects of the environments where interaction networks are studied must be considered in order to fully understand the predominant patterns and processes in ecological networks. The two interaction networks between flower-visiting social wasps and plants evaluated in this study presented remarkable differences directly related to variation in landscape. In general, networks involving floral visitors 
TABle 2: Abundance, number of plant species visited, and niche amplitude of the species of social wasps collected in Ibitipoca State Park, MG, Brazil, during the period from November 2007 to October 2008. "RF” means Riparian Forest and "RG” means Rocky Grassland. See Table 3 for the classification and authors of species.

\begin{tabular}{|c|c|c|c|c|c|c|}
\hline \multirow{2}{*}{ Wasp species } & \multicolumn{2}{|c|}{ Abundance of individuals } & \multicolumn{2}{|c|}{ No. of plant species visited } & \multicolumn{2}{|c|}{ Niche amplitude $\left(H^{\prime}\right)$} \\
\hline & $\mathrm{RF}$ & RG & $\mathrm{RF}$ & RG & $\mathrm{RF}$ & RG \\
\hline Mischocyttarus confusus & 16 & 1 & 8 & 1 & 1.808 & 0 \\
\hline Polybia sp. 1 & 14 & 7 & 5 & 3 & 1.400 & 0.955 \\
\hline Polybia paulista & 16 & 2 & 6 & 1 & 1.548 & 0 \\
\hline Polistes billardieri & 4 & 1 & 3 & 1 & 1.040 & 0 \\
\hline Mischocyttarus drewseni & 11 & 6 & 7 & 5 & 1.768 & 1.561 \\
\hline Protonectarina sylveirae & 7 & 1 & 3 & 1 & 0.796 & 0 \\
\hline Polistes sp. 1 & 2 & 0 & 2 & 0 & 0.693 & - \\
\hline Polybia sericea & 2 & 0 & 2 & 0 & 0.693 & - \\
\hline Apoica pallens & 2 & 1 & 1 & 1 & 0 & 0 \\
\hline Polistes ferreri & 2 & 1 & 1 & 1 & 0 & 0 \\
\hline Polybia ignobilis & 3 & 0 & 2 & 0 & 0.636 & - \\
\hline Agelaia multipicta & 1 & 0 & 1 & 0 & 0 & - \\
\hline Brachygastra lecheguana & 1 & 0 & 1 & 0 & 0 & - \\
\hline Polistes cinerascens & 1 & 0 & 1 & 0 & 0 & - \\
\hline Polybia fastidiosuscula & 1 & 0 & 1 & 0 & 0 & - \\
\hline
\end{tabular}

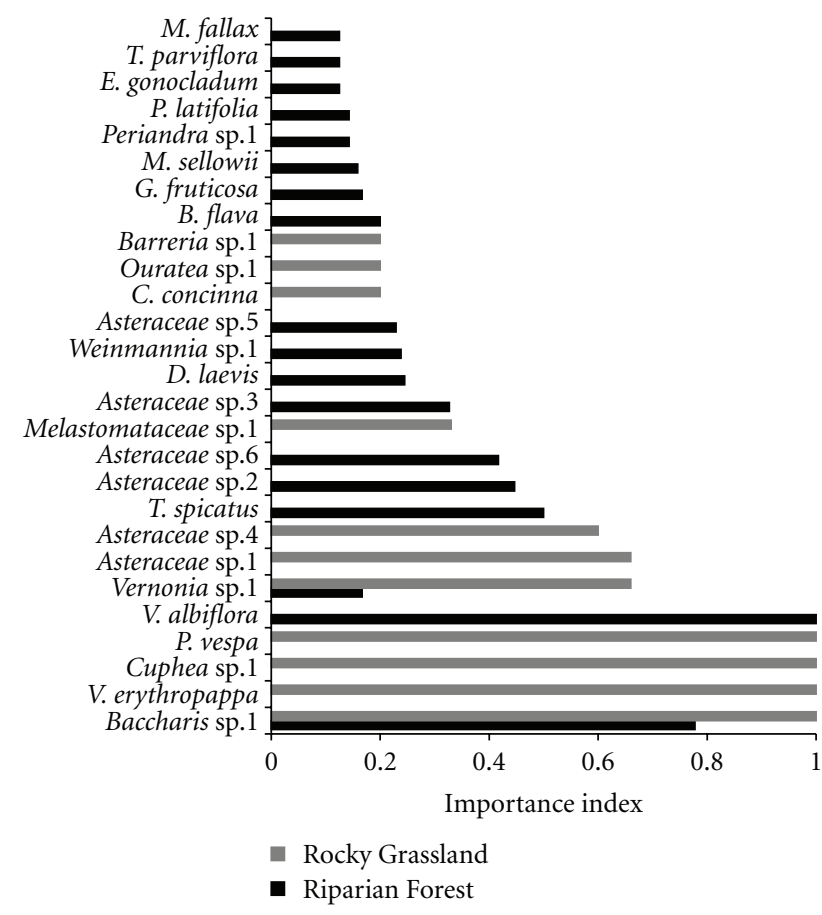

FIGURe 2: Importance index of plant species in the two areas of Ibitipoca State Park (Riparian Forest and Rocky Grassland), MG, Brazil, during the period from November 2007 to October 2008.

and plants present a nested pattern and intermediate levels of specialization $[6,15,16,51]$. Nevertheless, we observed two distinct patterns between the areas assessed: a more generalist (significant nestedness and lower specialization degree) and a more specialist pattern (without significant nestedness and with larger specialization degree than 0.5 ). The species degrees also showed the differences of network patterns

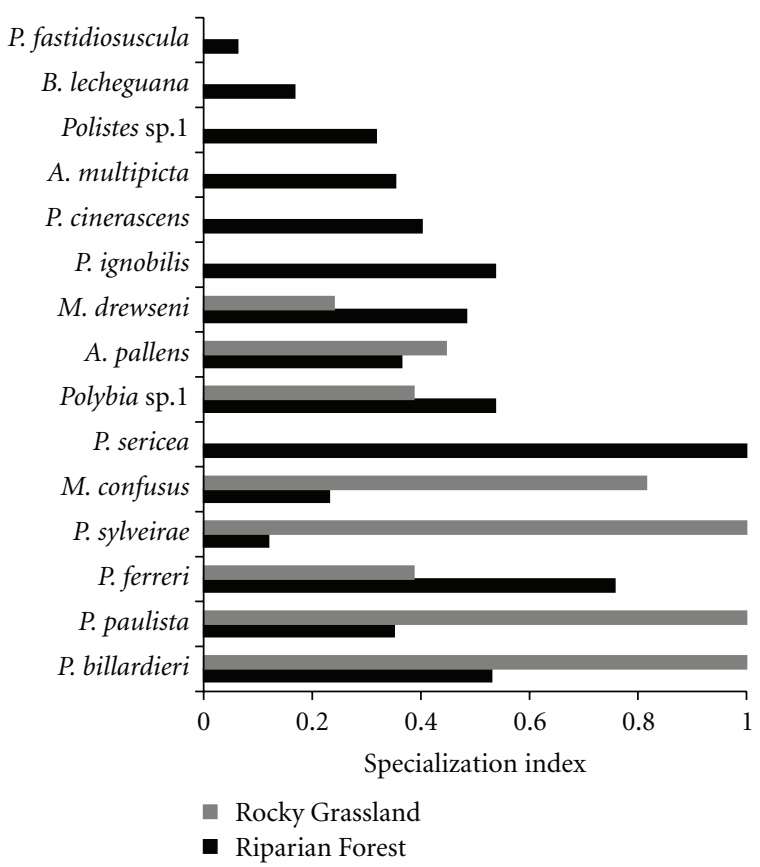

FIGURE 3: Specialization index of social wasp species in the two areas of Ibitipoca State Park (Riparian Forest and Rocky Grassland), MG, Brazil, during the period from November 2007 to October 2008.

(Table 1). Despite these differences, both networks showed asymmetry, with larger number of plant species than wasp species. This result does not corroborate the structure of other pollinator-plant networks, which involve a much higher number of pollinators than plant species [15]. In these networks, pollinators are significantly less specialized on plants than plants on pollinators. Here we found 
TABLE 3: Classification and authors of species.

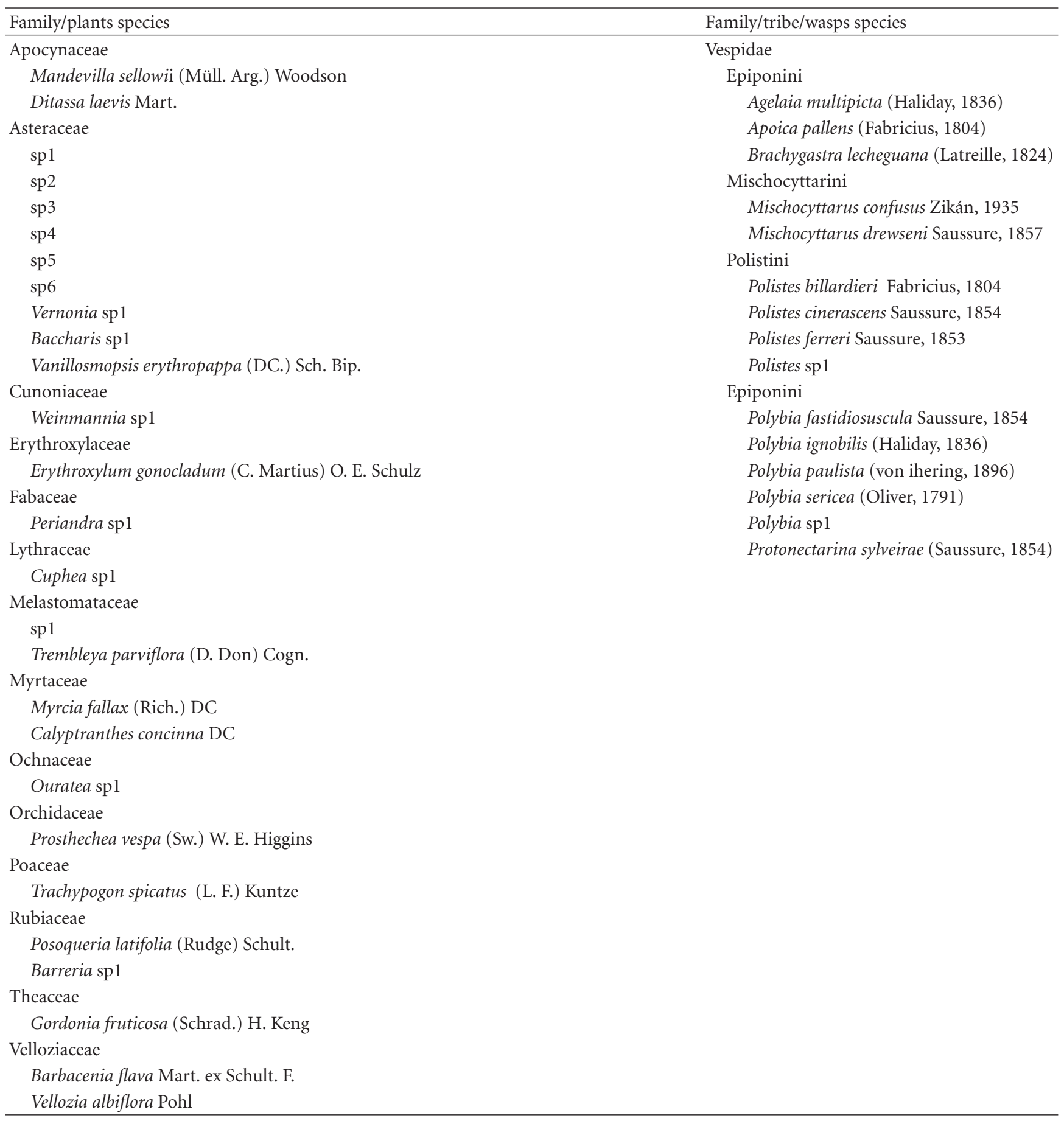

the opposite: pollinators were more specialized in plants than the plants on pollinators.

This result can be explained for differences in environmental complexity between the two physiognomies. The Riparian Forest and the Rocky Grassland present distinct vegetation patterns, sharing few plant species in common and exhibiting different microclimatic conditions [37]. The Riparian Forest is always more humid and shady, while the Rocky Grassland is more sunny and presents wider variation in the thermal amplitude and in the yearly and daily humidity, as a general reference. The greater complexity of the interaction network concerning flower-visiting social wasps found in the Riparian Forest can also be explained by the heterogeneity of the vegetation at this site and wider diversity of niches. The Riparian Forest in Ibitipoca State Park is characterized by a sequence of physiognomies with shrubby arboreal to predominantly arboreal formations near water sources [37], which is ideal for wasps to build its nests. 
Contrastingly, the Rocky Grassland presents a structure with a wide diversity of herbs, grasses, and shrubs distributed over quartzite outcrops [37]. Santos [36], studying communities of social wasps associated with a mangrove swamp, the Atlantic Forest, and the Restinga Forest (coastal plain vegetation), reported that the diversity of wasps found in each of these tropical ecosystems was significantly correlated with the diversity of plants because they provide more substrates for nesting $[52,53]$, more amount of food recourses (i.e., nectar $[25,28,54])$, more materials for nest construction (i.e., plant fibers $[55,56]$ ), and more areas for prey foraging [57]. Therefore, the vegetation complexity is of decisive importance in the composition and structure of the social wasp communities, directly influencing their niches and their associations [36]. In this manner, the differences found in the two networks evaluated here may reflect the landscape characteristics, which are responsible not only for the increase in the richness and abundance of the interactions in the environments, but also for the establishment of a more generalist or specialist pattern in its interaction network with plants.

On the other hand, although the environmental complexity is related to the abundance of individuals and species, the behavioral characteristics of the species also have to be regarded as a relevant factor in the network composition and structure. Species such as Protonectarina sylveirae (Saussure, 1854), Polybia sericea (Olivier, 1791), Polybia paulista (Ihering, 1896), Apoica pallens (Fabricius, 1804), Brachygastra lecheguana (Latreille, 1824), Polistes canadensis (Linnaeus, 1758), and Polistes ignobilis (Haliday, 1836) present a wider range of ecological tolerance than other species and are generally dominant in open ecosystems, with standing severe environmental conditions such as in the Rocky Grassland [36].

In this context, the complexity of the two phytophysiognomies, as well as the behavioral characteristics of the species involved in the interactions between flower-visiting social wasps and plants, is an important factor to establish the network patterns found in the present study. Hence, an environment of greater niche complexity and plant species diversity provides better conditions for the maintenance of more complex networks, where interactions are concentrated on generalist species, thus forming a network with a nested structure and asymmetric specialization. A recent study showed that species diversity influences the network pattern [58]. In this study, the author showed that sites with greater richness and diversity of species tend to overlap connections in network and consequently increase the generalization of network interactions. Conversely, environments with reduced complexity may shape interactions by making them more specialized [29], as evidenced in the Rocky Grassland network. However, this result was not previously tested for interactions between social wasps and plants.

The variation in the values of niche amplitude found in this study for wasps may be related to factors that influence the foraging activity [57]. Social wasps have in floral nectar its main food source $[59,60]$, what may be associated to the facility to access this resource compared with the energy spent to search, subdue, and capture a prey [61]. This fact is more evident in species bearing small colonies like Mischocyttarus, the most abundant and with higher niche amplitude group in this study. On the other hand, differences in the biomass of some species may also influence foraging activities of social wasps [57]. Populations with higher biomass use a greater amount of food resources [28]. This could explain the wider foraging spectrum of genus Polybia and also greater abundance of visiting individual flowers. These wasps build large nests that have many individuals. According to Spradbery [62], size can be a decisive factor for resource consumption, affecting the foraging amplitude of these species, and the colony productivity may influence the foraging activity.

An additional factor determining the foraging pattern of social wasps is plant-flowering phenology, what directly influences resources abundance and distribution [2], see also [63]. A higher diversity of plant species may increase over time the variety, quality, and availability of resources for flower visitors, like wasps $[28,64,65]$. The niche amplitude as well as the specialization degree should be directly related with environment characteristics, including its seasonal variations (see [66]).

Although more than half of the plants were visited by only one to three individuals and wasp species, leading to a low importance index for most plant species in both areas, this result corroborates the observations by Heithaus [1] and Santos et al. [28]. Nevertheless, some plant species may be visited very frequently, as observed to Asteraceae, which was involved in most interactions. This result may be related to the wide distribution of this family species in the Rocky Grassland and in the Riparian Forest of Ibitipoca State Park. Furthermore, this frequent visitation to Asteraceae is also probably due to the anatomy of their flowers, which present a brush-like inflorescence with a great number of small compact flowers, making them more conspicuous to insects [67]. Asteraceae species usually have bright colored yellow or white flowers, effectively attracting insects [68], and they also present abundant amounts of nectar, which is located at a depth of just a few millimeters, ideal for the size of wasp mouthparts $[68,69]$.

The flowers of the Baccharis sp1 were the most visited considering the abundance of individuals and richness of species in the two phytophysiognomies, showing them to be of great importance to the interaction network between social wasps and plants of Ibitipoca. In southern Brazil, Hermes and Köhler [10] observed that $28 \%$ of the individual wasps collected were found on flowers of Baccharis, the second most visited genus by this species of social wasp. These researchers also reported that $M$. drewseni females were captured mainly on Baccharis tridentata and Baccharis myriocephala. In a general context, although social wasps are rarely regarded as pollinators, with varying effectiveness according to the species associated [70], they act as regular visitors to flowers in various environments. Thus, the conservation of these wasp species may be relevant to the maintenance of diversity in natural communities.

Currently, research into networks in interaction studies is beginning to attach importance to the factors that shape the properties of interaction networks. However, most studies 
involving networks of interactions between organisms still relate the network pattern only to the type of interaction established between the groups $[15,16,71,72]$. Our results, despite having a small sampling of the wasp-plant interaction network, suggest that differences in structural complexity of the environment directly influence the structure of the interaction network between flower-visiting social wasps and plants. Hence, knowing the biotic and abiotic factors of the sites in which such interactions take place is of fundamental importance to define and understand the structure of the networks established in these areas. Therefore, research concerning network patterns of different types of interactions established between organisms contributes to a more complete understanding of the ecology of communities in distinct environments.

\section{Acknowledgments}

The authors wish to thank F. Salimena and L. Menini (Leopoldo Krieger Herbarium) for support in the identification of the botanical material and E. Giannotti for the identification of social wasp species. They also wish to recognize the Universidade Federal de Juiz de Fora (UFJF), the Coordenação de Aperfeiçoamento Pessoal de Nível Superior (CAPES) (M. A. Clemente: doctoral fellowship), and the Conselho Nacional de Desenvolvimento Científico e Tecnológico (CNPq) (K. Del-Claro: 476074/2008-8, 472046/ 2011-0, and 301248/2009-5, D. Lange: AT/500868/20107) for financial support and the Instituto Estadual de Floresta de Minas Gerais (IEF/MG) for logistical support.

\section{References}

[1] E. R. Heithaus, "Community structure of Neotropical flower visiting bees and wasps: diversity and phenology," Ecology, vol. 60, pp. 190-202, 1979.

[2] E. R. Heithaus, "Flower-feeding specialization in wild bee and wasp communities in seasonal neotropical habitats," Oecologia, vol. 42, no. 2, pp. 179-194, 1979.

[3] J. H. Hunt, P. A. Bown, K. M. Sago, and J. A. Kerker, "Vespid Wasps eat pollen (Hymenoptera: Vespidae)," Journal of the Kansas Entomological Society, vol. 64, no. 2, pp. 127-130, 1991.

[4] G. D. Jones and S. D. Jones, "The uses of pollen and its implication for entomology," Neotropical Entomology, vol. 30, no. 3, pp. 341-350, 2001.

[5] E. A. Nascimento and K. Del-Claro, "Floral visitors of Chamaecrista debilis (Vogel) Irwin \& Barneby (FabaceaeCaesalpinoidea) at Cerrado of Estação Ecológica de Jataí, São Paulo State, Brazil," Neotropical Entomology, vol. 36, no. 4, pp. 619-624, 2007.

[6] G. M. D. M. Santos, C. M. L. Aguiar, and M. A. R. Mello, "Flower-visiting guild associated with the Caatinga flora: trophic interaction networks formed by social bees and social wasps with plants," Apidologie, vol. 41, no. 4, pp. 466-475, 2010.

[7] A. Shuttleworth and S. D. Johnson, "The importance of scent and nectar filters in a specialized wasp-pollination system," Functional Ecology, vol. 23, no. 5, pp. 931-940, 2009.

[8] R. B. Sühs, A. Somavilla, A. Köhler, and J. Putzke, "Vespídeos (Hymenoptera, Vespidae) vetores de pólen de Schinus terebinthifolius Raddi (Anacardiaceae), Santa Cruz do Sul, RS, Brasil," Revista Brasileira de Epidemiologia, vol. 7, pp. 138-143, 2009.

[9] M. G. E. Barros, "Sistemas reprodutivos e polinização em espécies simpátricas de Ehroxylum P. Br. (Erythroxylaceae) do Brasil," Revista Brasileira de Botânica, vol. 21, no. 2, pp. 159166, 1998.

[10] M. G. Hermes and A. Köhler, "The flower-visiting social wasps (Hymenoptera, Vespidae, Polistinae) in two areas of Rio Grande do Sul State, southern Brazil," Revista Brasileira de Entomologia, vol. 50, no. 2, pp. 268-274, 2006.

[11] D. P. Vázquez, N. Blüthgen, L. Cagnolo, and N. P. Chacoff, "Uniting pattern and process in plant-animal mutualistic networks: a review," Annals of Botany, vol. 103, no. 9, pp. 14451457, 2009.

[12] J. Bascompte, P. Jordano, C. J. Melián, and J. M. Olesen, "The nested assembly of plant-animal mutualistic networks," Proceedings of the National Academy of Sciences of the United States of America, vol. 100, no. 16, pp. 9383-9387, 2003.

[13] P. Jordano, J. Bascompte, and J. M. Olesen, "Invariant properties in coevolutionary networks of plant-animal interactions," Ecology Letters, vol. 6, no. 1, pp. 69-81, 2003.

[14] J. M. Olesen, J. Bascompte, Y. L. Dupont, and P. Jordano, "The modularity of pollination networks," Proceedings of the National Academy of Sciences of the United States of America, vol. 104, no. 50, pp. 19891-19896, 2007.

[15] N. Blüthgen, F. Menzel, T. Hovestadt, B. Fiala, and N. Blüthgen, "Specialization, constraints, and conflicting interests in mutualistic networks," Current Biology, vol. 17, no. 4, pp. 341-346, 2007.

[16] N. Blüthgen, "Ecologia das interações Animais-Plantas: interações Planta-Animais e a importância funcional da biodiversidade," in Ecologia das Interações Plantas-Animais: Uma Abordagem Evolutiva, K. Del-Claro and H. M. Torezan-Silingardi, Eds., pp. 261-272, Technical Books Editora, Rio de Janeiro, Brazil, 2012.

[17] U. Bastolla, M. A. Fortuna, A. Pascual-García, A. Ferrera, B. Luque, and J. Bascompte, "The architecture of mutualistic networks minimizes competition and increases biodiversity," Nature, vol. 458, no. 7241, pp. 1018-1020, 2009.

[18] N. Blüthgen and A. M. Klein, "Functional complementarity and specialisation: the role of biodiversity in plant-pollinator interactions," Basic and Applied Ecology, vol. 12, no. 4, pp. 282291, 2011.

[19] J. M. Montoya, S. L. Pimm, and R. V. Solé, "Ecological networks and their fragility," Nature, vol. 442, no. 7100, pp. 259264, 2006.

[20] C. Fontaine, E. Thébault, and I. Dajoz, "Are insect pollinators more generalist than insect herbivores?" Proceedings of the Royal Society B, vol. 276, no. 1669, pp. 3027-3033, 2009.

[21] E. Thébault and C. Fontaine, "Stability of ecological communities and the architecture of mutualistic and trophic networks," Science, vol. 329, no. 5993, pp. 853-856, 2010.

[22] M. A. R. Mello, G. M. D. M. Santos, M. R. Mechi, and M. G. Hermes, "High generalization in flower-visiting networks of social wasps," Acta Oecologica, vol. 37, no. 1, pp. 37-42, 2011.

[23] C. M. L. Aguiar and G. M. M. Santos, "Compartilhamento de recursos florais por vespas sociais (Hymenoptera: Vespidae) e abelhas (Hymenoptera: Apoidea) em uma área de caatinga," Neotropical Entomology, vol. 36, no. 6, pp. 836-842, 2007.

[24] M. R. Mechi, "Comunidade de vespas Aculeata (Hymenoptera) e suas fontes florais," in O Cerrado Pé-de-Gigante: Ecologia e conservação Parque Estadual Vassununga, 
V. R. Pivello and E. M. Varanda, Eds., pp. 256-265, Secretaria do Meio Ambiente, São Paulo, Brazil, 2005.

[25] V. D. A. Silva-Pereira and G. M. M. Santos, "Diversity in bee (Hymenoptera: Apoidea) and social wasp (Hymenoptera: Vespidae, Polistinae) community in "Campos Rupestres", Bahia, Brazil," Neotropical Entomology, vol. 35, no. 2, pp. 165174, 2006.

[26] A. Elpino-Campos, K. Del-Claro, and F. Prezoto, "Diversity of Social Wasps (Hymenoptera: Vespidae) in the Cerrados of Uberlândia, Minas Gerais State, Brazil," Neotropical Entomology, vol. 36, no. 5, pp. 685-692, 2007.

[27] L. R. S. Zanette, R. P. Martins, and S. P. Ribeiro, "Effects of urbanization on Neotropical wasp and bee assemblages in a Brazilian metropolis," Landscape and Urban Planning, vol. 71, no. 2-4, pp. 105-121, 2005.

[28] G. M. D. M. Santos, C. M. L. Aguiar, and N. Gobbi, "Characterization of the social wasp guild (Hymenoptera: Vespidae) visiting flowers in the Caatinga (Itatim, Bahia, Brazil)," Sociobiology, vol. 47, no. 2, pp. 483-494, 2006.

[29] N. Blüthgen, J. Fründ, D. P. Vazquez, and F. Menzel, "What do interaction network metrics tell us about specialization and biological traits?" Ecology, vol. 89, no. 12, pp. 3387-3399, 2008.

[30] J. L. Bronstein, "The contribution of ant-plant protection studies to our understanding of mutualism," Biotropica, vol. 30, no. 2, pp. 150-161, 1998.

[31] K. Del-Claro and P. S. Oliveira, "Conditional outcomes in a neotropical treehopper-ant association: temporal and speciesspecific variation in ant protection and homopteran fecundity," Oecologia, vol. 124, no. 2, pp. 156-165, 2000.

[32] K. Del-Claro and H. M. Torezan-Silingardi, "Insect-plant interactions: new pathways to a better comprehension of ecological communities in Neotropical savannas," Neotropical Entomology, vol. 38, no. 2, pp. 159-164, 2009.

[33] E. R. Pianka, Evolutionary Ecology, Harper and Row, Harper \& Row, New York, NY, USA, 3rd edition, 1983.

[34] E. O. Wilson, Biodiversity, National Academy Press, Washington, DC, USA, 1988.

[35] G. M. M. Santos, Comunidade de vespas sociais (HymenopteraPolistinae) em três ecossistemas do Estado da Bahia, com ênfase na estrutura da guilda de vespas visitantes de flores de Caatinga [Tese de Doutorado], Universidade de São Paulo, Ribeirão Preto, Brazil, 2000.

[36] G. M. D. M. Santos, C. C. Bichara Filho, J. J. Resende, J. D. da Cruz, and O. M. Marques, "Diversity and community structure of social wasps (Hymenoptera: Vespidae) in three ecosystems in Itaparica Island, Bahia State, Brazil," Neotropical Entomology, vol. 36, no. 2, pp. 180-185, 2007.

[37] L. G. Rodela, "Cerrados de altitude e campos rupestres do Parque Estadual do Ibitipoca, sudeste de Minas Gerais: distribuição e florística por subfisionomias da vegetação," Revista do Departamento de Geografia, vol. 12, pp. 163-189, 1999.

[38] G. Durigan, R. R. Rodrigues, and I. Schiavini, "A heterogeneidade ambiental definindo a metodologia de amostragem da floresta ciliar," in Matas Ciliares: Conservação e Recuperação, R. R. Rodrigues and H. F. Leitão-Filho, Eds., pp. 159-167, EDUSP, São Paulo, Brazil, 2000.

[39] M. A. L. Fontes, Análise da composição florística das florestas nebulares do Parque Estadual do Ibitipoca, Minas Gerais [Dissertação de Mestrado], Universidade Federal de Lavras, Minas Gerais, Brazil, 1997.

[40] A. M. Giulietti, J. R. Pirani, and R. M. Harley, "Espinhaço range region, eastern Brazil," in Centers of Plant Diversity: A Guide and Strategy for Their Conservation, S. D. Davis, V. H.
Heywood, O. Herrera-MacBryde, J. Villa-Lobos, and A. C. Hamilton, Eds., pp. 397-404, World Wildlife Fund \& World Conservation Union, 1997.

[41] C. M. L. Aguiar, "Utilização de recursos florais por abelhas (Hymenoptera: Apoidea) em uma área de caatinga (Itatim, Bahia, Brasil)," Revista Brasileira de Zoociênciasvol, vol. 20, pp. 457-467, 2003.

[42] O. W. Richards, The Social Wasps of Americas Excluding the Vespinae, British Museum, London, UK, 1978.

[43] J. M. Carpenter and O. M. Marques, "Contribuição ao estudo de vespídeos do Brasil (Insecta: Hymenoptera: Vespoidea, Vespidae)," Série: Publicações digitais vol. 2, versão 1. 0, 2001.

[44] P. Jordano, "Patterns of mutualistic interactions in pollination and seed dispersal: connectance, dependence asymmetries, and coevolution," American Naturalist, vol. 129, no. 5, pp. 657-677, 1987.

[45] J. A. Dunne, "The network structure of food webs," in Ecological Networks: Linking Structure to Dynamic in Food Webs, M. Pascual and J. A. Dunne, Eds., pp. 325-347, Oxford University Press, Oxford, UK, 2006.

[46] D. P. Vázquez, C. J. Melián, N. M. Williams, N. Blüthgen, B. R. Krasnov, and R. Poulin, "Species abundance and asymmetric interaction strength in ecological networks," Oikos, vol. 116, no. 7, pp. 1120-1127, 2007.

[47] M. Almeida-Neto, P. R. Guimarães Jr., J. P. R. Guimaraes, R. D. Loyola, and W. Ulrich, "A consistent metric for nestedness analysis in ecological systems: reconciling concept and measurement," Oikos, vol. 117, no. 8, pp. 1227-1239, 2008.

[48] P. R. Guimaraes Jr. and P. Guimarães, "Improving the analyses of nestedness for large sets of matrices," Environmental Modelling and Software, vol. 21, no. 10, pp. 1512-1513, 2006.

[49] N. Blüthgen, F. Menzel, and N. Blüthgen, "Measuring specialization in species interaction networks," BMC Ecology, vol. 6, article 9, 2006.

[50] K. G. Murray, "The importance of different bird species as seed dispersers," in Monteverde: Ecology and Conservation of a Tropical Cloud Forest, N. M. Nadkarni and N. T. Wheelwright, Eds., pp. 284-295, Oxford University Press, New York, NY, USA, 2000.

[51] T. M. Lewinsohn, L. R. Jorge, and P. I. Prado, "Biodiversidade e interações entre insetos herbívoros e plantas," in Ecologia das Interações Plantas-Animais: uma Abordagem Evolutiva, K. Del-Claro and H. M. Torezan-Silingardi, Eds., pp. 275-289, Technical Books Editora, Rio de Janeiro, Brazil, 2012.

[52] G. M. M. Santos and N. Gobbi, "Nesting habits and colonial productivity of Polistes canadensis canadensis(L.) (hymenoptera-vespidae) in a Caatinga area, Bahia state- Brazil," Journal of Advanced Zoology, vol. 19, no. 2, pp. 63-69, 1998.

[53] J. D. Cruz, E. Giannotti, G. M. M. Santos, C. C. Bichara-Filho, and A. A. Rocha, "Nest site selection and flying capacity of neotropical wasp Angiopolybia pallens (Hymenoptera: Vespidae) in the Atlantic Rain Forest, Bahia State, Brazil," Sociobiology, vol. 47, no. 3, pp. 739-750, 2006.

[54] J. Byk and K. Del-Claro, "Ant-plant interaction in the Neotropical savanna: direct beneficial effects of extrafloral nectar on ant colony fitness," Population Ecology, vol. 53, no. 2, pp. 327-332, 2011.

[55] V. L. L. Machado, "Plants which supply, "hair" material for nest building of Protopolybia sedula (Saussure, 1984)," in Social Insects in Tropics, P. Jaisson, Ed., pp. 189-192, University ParisNord, Paris, Farnce, 1982.

[56] O. M. Marques and C. A. L. Carvalho, "Hábitos de nidificação de vespas sociais (Hymenoptera: Vespidae) no município de 
Cruz das Almas, Estado da Bahia," Insecta, vol. 2, pp. 23-40, 1993.

[57] G. M. M. Santos, S. O. C. Silva, C. C. Bichara Filho, and N. Gobbi, "Influencia del tamaño del cuerpo en el forrajeo de avispas sociales (Hymenoptera: Polistinae) visitantes de Syagrus coronata(Martius) (Arecacea)," Revista Brasileira de Zoociências, vol. 62, pp. 167-170, 1998.

[58] A. Baselga, "Partitioning the turnover and nestedness components of beta diversity," Global Ecology and Biogeography, vol. 19, no. 1, pp. 134-143, 2010.

[59] J. J. Resende, G. M. M. Santos, C. C. Bichara-Filho, and M. Gimenes, "Atividade diária de busca de recursos pela vespa social Polybia occidentalis (Olivier, 1791) (Hymenoptera, Vespidae)," Revista Brasileira de Zoociências, vol. 3, no. 1, pp. 105-115, 2001.

[60] F. R. Andrade and F. Prezoto, "Horários de atividade forrageadora e material coletado por Polistes ferreri Saussure, 1853 (Hymenoptera, Vespidae), nas diferentes fases de seu ciclo biológico," Revista Brasileira de Zoociências, vol. 3, no. 1, pp. 117-128, 2001.

[61] M. Tindo and A. Dejean, "Rhythm of activity and feeding behavior of Belonogaster juncea juncea (Hymenoptera: Vespidae)," Sociobiology, vol. 32, no. 1, pp. 101-107, 1998.

[62] J. P. Spradbery, Wasps: Account of the Biology and Natural History of Social and Solitary Wasps, University of Washington Press, Seattle, Wash, USA, 1973.

[63] S. Almeida-Soares, L. P. Polatto, J. C. S. Dutra, and H. M. Torezan-Silingardi, "Pollination of Adenocalymma bracteatum (Bignoniaceae): floral biology and visitors," Neotropical Entomology, vol. 39, no. 6, pp. 941-948, 2010.

[64] A. S. Corbet, D. M. Unwin, and O. Prys-Jones, "Humidity, néctar and insect visits to flowers, with reference to Crataegus, Tilia and Echium," Ecological Entomology, vol. 4, pp. 9-22, 1979.

[65] M. M. Kwak, Y. A. Holthuijzen, and H. H. T. Prins, "A comparison of nectar characteristics of the bumblebee- pollinated Rhinanthus minor and R. serotinus," Oikos, vol. 44, no. 1, pp. 123-126, 1985.

[66] E. Camillo and C. A. Garofalo, "Analysis of the niche of two sympatric species of Bombus (Hymenoptera, Apidae) in southeastern Brazil," Journal of Tropical Ecology, vol. 5, no. 1, pp. 81-92, 1989.

[67] M. Proctor, O. Yeo, and A. Lack, The Natural History of Pollination, Harper Collins Publishers, Hampshire, UK, 1996.

[68] K. Faegri and L. van der Pijl, The Principles of Pollination Ecology, Pergamon Press, London, UK, 1979.

[69] H. M. Torezan-Silingardi, "Flores e animais: uma introdução a historia natural da polinização," in Ecologia das Interações Plantas-Animais: uma Abordagem Evolutiva, K. Del-Claro and H. M. Torezan-Silingardi, Eds., pp. 111-140, Technical Books Editora, Rio de Janeiro, Brazil, 2012.

[70] R. Gadagkar, "Belonogaster, Mischocyttarus, Parapolybia, and independent-founding Ropalidia," in The Social Biology of Wasps, K. G. Ross and R. W. Matthews, Eds., pp. 149-190, Cornell University Press, Ithaca, NY, USA, 1991.

[71] P. R. Guimaraes Jr., V. Rico-Gray, P. Oliveira, T. J. Izzo, S. F. dos Reis, and J. N. Thompson, "Interaction intimacy affects structure and coevolutionary dynamics in mutualistic networks," Current Biology, vol. 17, no. 20, pp. 1797-1803, 2007.

[72] J. Bascompte, "Disentangling the web of life," Science, vol. 325, no. 5939, pp. 416-419, 2009. 

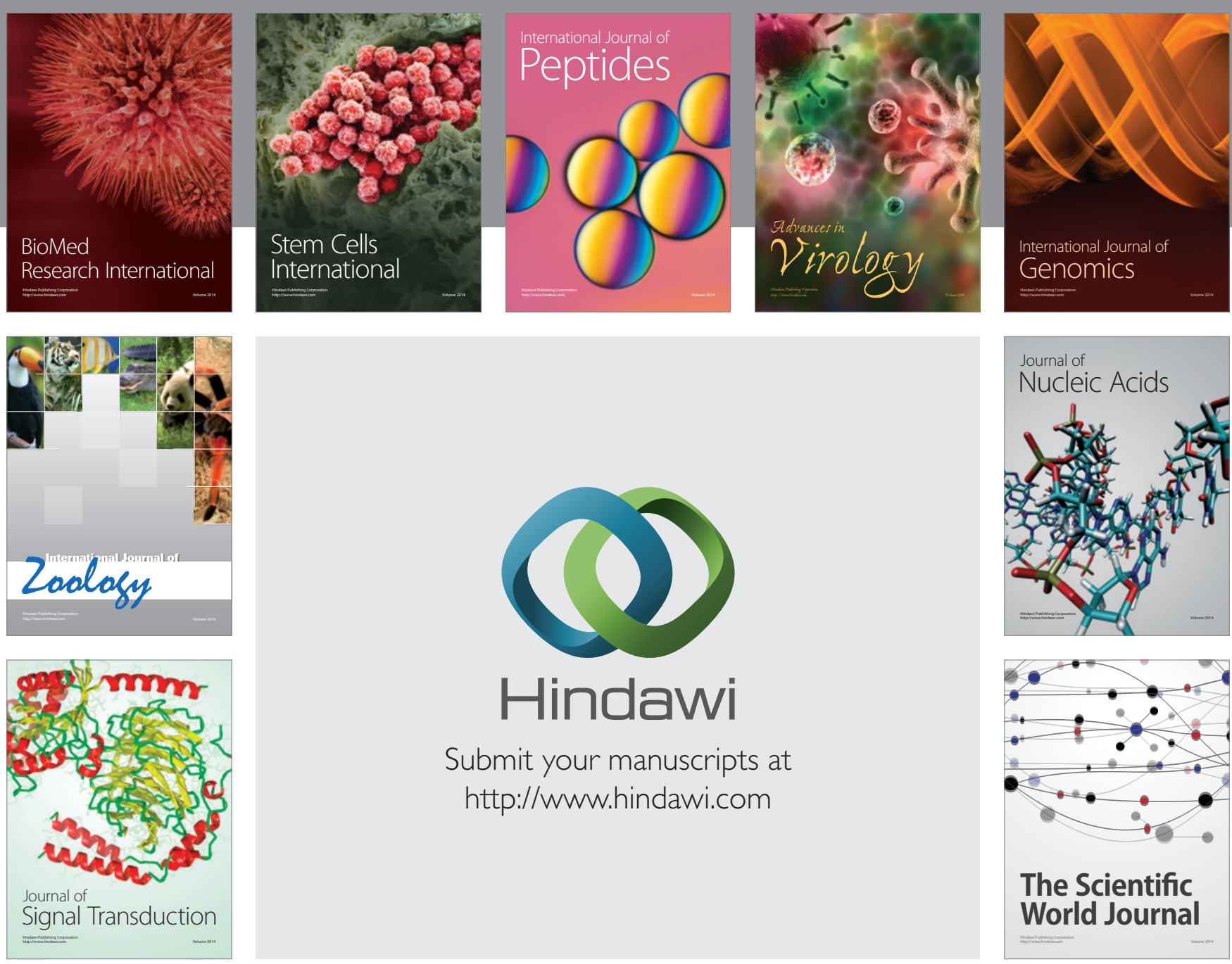

Submit your manuscripts at

http://www.hindawi.com
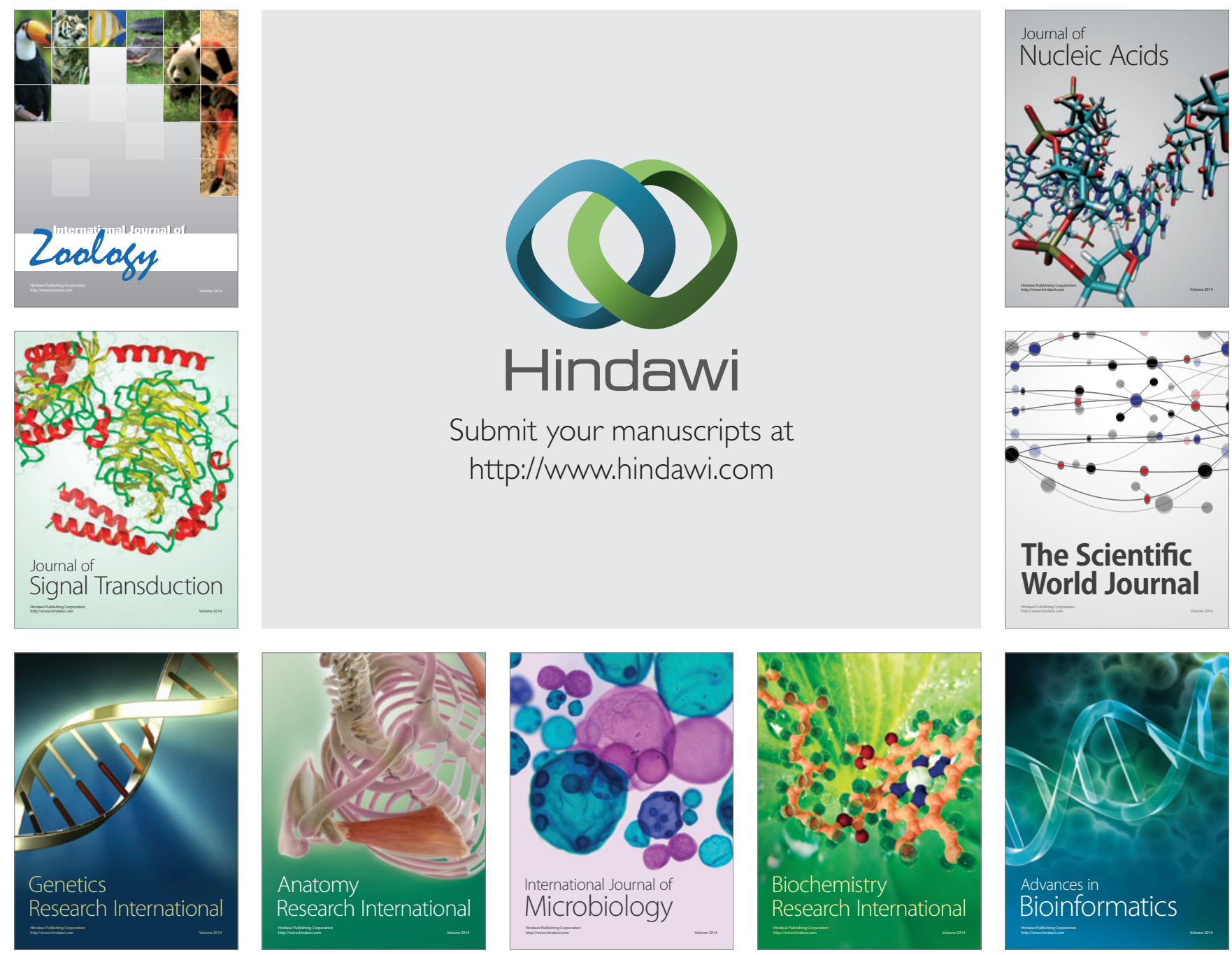

The Scientific World Journal
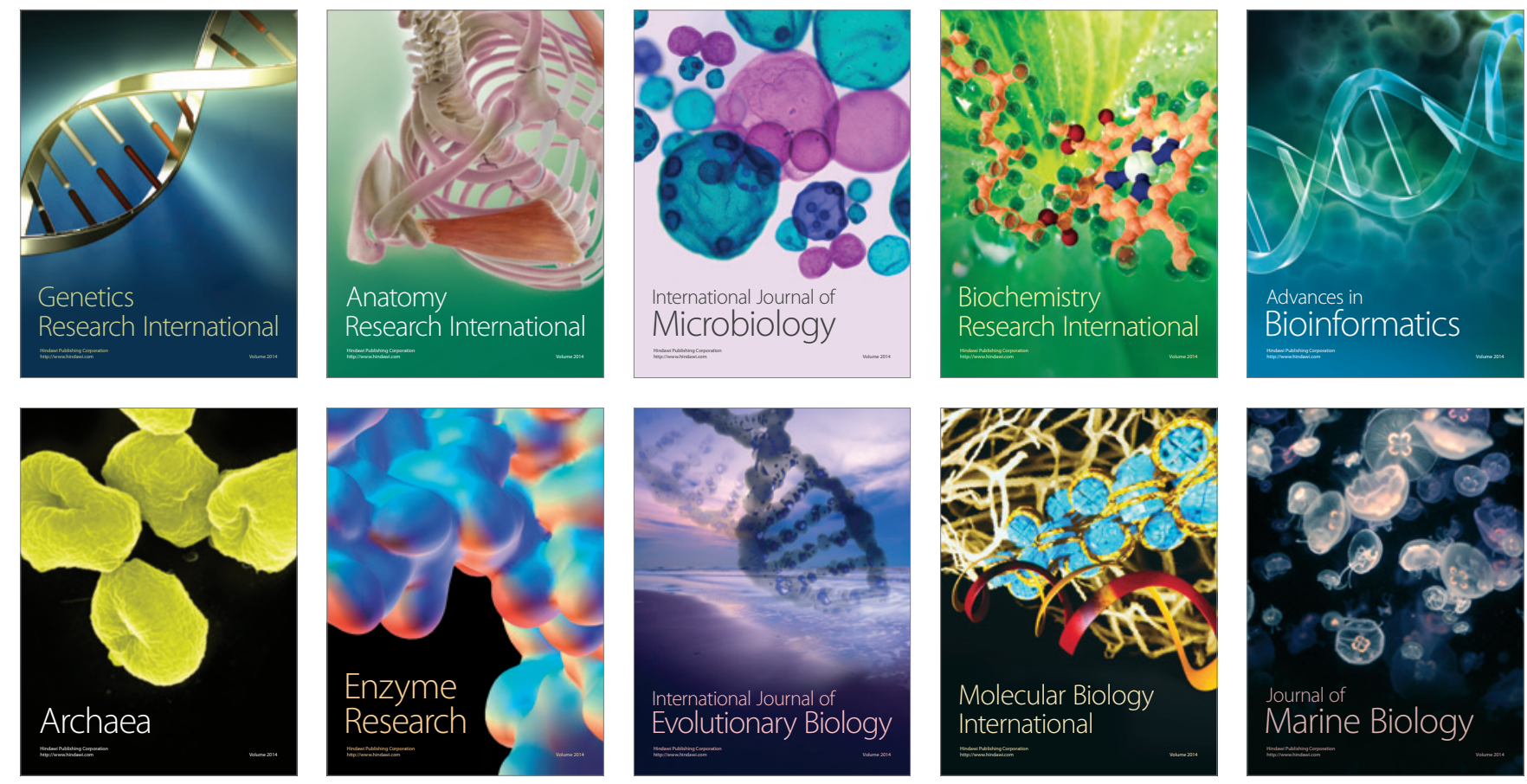